\title{
Space Law: the Present and the Future
}

\author{
Valentyn Halunko \\ Doctor of Law, Professor, Research Institute of Public Law \\ (Kyiv, Ukraine) \\ E-mail: halunko@i.ua \\ https://orcid.org/0000-0003-1619-5028
}

The article suggests a comprehensive analysis of the current trends in the development of space law. The principles of space law have been adjusted. The limits of understanding of space law have been expanded and supplemented with the scientific understanding of the sources of space law. The authors disclosed trade regulation factors in outer space. The legal aspects of the militarization of outer space and space debris have been clarified. The advanced tasks of space law have been identified, namely: standardization of legal space terms, approval of private space law, stimulation of private capital involvement in space programs, development of the theory of the right to use space bodies, regulation of the rights and legitimate interests of space tourists, development of sanctions agreed by the world community for violation of space law, subjects and procedures for their application.

Keywords: space body, state, Earth, outer space, space, man, international sanctions, space law, private companies, space debris, weapons

Received: March 01, 2019; accepted: April 07, 2019

Advanced Space Law, Volume 3, 2019: 30-47.

https://doi.org/10.29202/asl/2019/3/3

\section{Introduction}

Humanity is actively developing. In the spatial dimension, the most promising direction of human development is boundless outer space, which extends from the atmosphere, from a height of 100-110 kilometres, the cradle of humanity — the planet Earth, at least 13.8 billion world years. The ancients wisely determined that the cosmos is the order (from the ancient Greek кó $\sigma \mu \mathrm{s}$ — “ “order”). This word was used as a counterbalance to the world disorder. Now a significant kind of space order is the legal space order, as a system of norms of space law.

More than 100 years of history has the category of "space law", which was first mentioned in the scientific works of French scientists (1910). Space law of that time was an amorphous idea without form and content. The first special monograph on space law was published in 1932. Short scientific publications that were devoted to space law appeared in the 1930s and 1940s, the first doctoral dissertation on this subject was defended in 1953 [Doyle, 2014].

(C) Halunko, Valentyn, 2019 
Therefore, the period before 1957 is a mythological, Sci-Fi and theoretical elucidation of probable social relations that could potentially arise and be governed by the law in the alleged human activity in outer space.

However, practical space law emerged in the most democratic way, with the instant Prince at the time of entering earth orbit on October 4, 1957, the first artificial earth satellite.

Further, in the 60 years of the XX century, the international community under the auspices of the UN approved the practical principles and norms of space law, which for almost 60 years successfully and without significant changes regulated social relations in outer space.

From the spatial point of view, it is not difficult to understand the limitless possibilities that humanity faces in outer space. Space exploration is the art of self-knowledge. The formation of space law is the art of creating norms of international and private space law in order for a person to live in harmony with other people, both in comic space and on the planet Earth, using the results of space research.

Space law actively developed in the 60 years of the XX century, then there was a period of long stagnation. In recent years, the development of space legislation has begun to revive. For example, in the UK in 2018, the "Law on the space industry" was adopted. Which spelt out licensing issues, regulatory requirements, legal liability and compensation for damage caused by the activities of private space companies [Smith \& Leishman , 2019].

All of this is due to the emergence of private business in outer space, a significant increase in the amount of space debris and potential attempts by some States to move the arms race into outer space. An increasing number of private actors operate in the space industry. This raises concerns about the adequate, both domestic and generally international legal framework for the regulation of commercial activities in space.

The business goes to space, classically see there is a profit. Accordingly, it is unlike the state will not invest in useless things for people. The private business invests only where it can make a profit. As a result, the business will provide new and cheaper useful space services in space or through space to individuals and legal entities. Mobile communication, global Internet system and navigation - all these factors of comfortable existence of modern man are inextricably linked with comic services.

In General, it should be emphasized that outer space is a limitless opportunity for its exploration and use. Including the limitless possibilities for the creation of a theory of space law, the theory of colonial space settlements and even States in space outside the planet Earth. A separate line should be noted the need to update the theory of guarantees of human rights, freedoms and legitimate interests in outer space, such as space tourists.

However, space law does not keep pace with the current pace of technology development. In addition, space law today is built largely outside the UN Committee on the peaceful uses of Outer Space (the Committee on the Peaceful Uses of Outer Space (hereinafter COPUOS)). Moreover, COPUOS is not always informed of new national legal developments in space law. It is also necessary to understand that the development of international space conventions and agreements, their harmonization and adoption requires much more time than is necessary for the development, testing and launch of new space technology. Accordingly, the role of COPUOS should be much higher. He has to work creatively ahead of the curve. Provide for relevant legal space issues and produce relevant scientific doctrines that require long debates of representatives of space powers. At a minimum, this will draw attention to a certain space problem, or may even lead to the harmonization and adoption of the texts of new international space agreements. [Benkoe \& Schrogl, 2005]. 
Thus: the active development of mankind, which is directed to outer space; the emergence of new subjects in the field of space law — private space companies; the need to resolve the militaristic aspects of space activities - require a new analysis of the current state of space law, to determine the aspects of its development.

First of all, the development of space law should be based on the standardization of legal space terms, the approval of private space law, the promotion of private capital involvement in space programs, the development of the theory of the right to use space bodies, the regulation of the rights and legitimate interests of space tourists, the development of sanctions for violations of space law, subjects and procedures for their application.

\section{Corrected principles of space law}

The world community has developed certain principles of space law, based on the first international space legal act, which was adopted by the UN General Assembly on December 13, 1963 "Declaration of legal principles of States 'activities in the exploration and use of outer space". This Treaty contains the fundamental principles of international space law in the form of the following recommendations: the exploration and use of outer space for the benefit and in the interests of all mankind; outer space and celestial bodies are free for all States and not subject to national appropriation; international law, including the UN Charter applied to outer space and celestial bodies; the activities of States in the exploration and use of outer space in the interest of international cooperation and understanding and should not create obstacles to such activities of other States; States bear international responsibility for national activities in the exploration and use of outer space, including the damage caused during this activity; state registration of object of space activity shall retain jurisdiction and control over such object, and any crew that are in it in space and after return to Earth; States regard astronauts as envoys of mankind and render them all necessary assistance to return to the country of registration in case of accident, distress or emergency landing on the territory of a foreign state.

These principles later formed the basis of the Treaty on principles governing the activities of States in the exploration and use of outer space, including the moon and other celestial bodies, which was adopted by the UN General Assembly on 13 December 1996 [Resolution, 1967].

Today, private space companies have begun to bring artificial earth satellites into near-earth orbit, using their own launch vehicles, so the principles of space law require adjustments. For example, Orsola Greco in his writings rightly rethinks the principles of space law in the context of the study and use of outer space and the problem of space debris propagation that originate from small satellites that are launched into low earth orbits [Greco, 2019].

Given the scientific debate that has been going on for decades, we will briefly and critically examine the basic principles of space law.

1. Good for all. According to scientists, the planet Earth is not eternal, so the "cradle of humanity" sooner or later can become the "coffin of humanity". The principle of space as a benefit to us applies not only to space but private space companies. The latter should act in accordance with the norms of international space law, the national space law of the state of registration and the state in which these companies have received permits (licenses) for the production and launch of launch vehicles and artificial satellites.

2. Openness. As a General rule, any state that has the relevant resources has the right to conduct certain activities in outer space. The moon, Venus, Mars, other planets and cosmic 
bodies may not be the property of any state or individual. In outer space is not valid in classical Roman private ownership. And therefore, when the first private company SpaceX, which is registered in the United States, went into space, there were no inconveniences for the world community due to its spacewalk. After all, the space activities of the first private space company SpaceX are regulated by the same rules that are used by the state space companies HASA.

Thus, the principle of openness in the conditions should be somewhat adjusted, namely: any space power, and a private person who has the appropriate tools and has received permission from the space power (license), has the right to conduct certain activities in outer space.

3. Cooperation. Space is a very expensive type of human activity, so the space powers cooperate and interact with each other in the field of research and use of outer space, involving in the process of interaction and private companies.

Types of cooperation (interaction) of private space companies are:

First, if a private company has obtained a permit (license) for the production and launch of spacecraft from a space state, in this case, the private company acts as a subject of international space law and is under the legal protection of the state in which it is registered and has received a permit for space activities. Therefore, public space law will be applied.

Secondly, if private space companies that are registered in different States interact with each other, their activities, along with international and national space law, will be governed by private space law. Now this situation cannot arise, because all private space companies are registered in one state of the United States - SpaceX, Boeing, Firefly, Aerospace, etc. Thus, international private space law is at the stage of its theoretical approval.

In the case of interaction (competition) of private companies of one state, their activities are regulated by national and international space legislation, which is ratified by such state. For example, in the United States on the principles of competition, various space companies are developing new comic technologies.

\section{The limits of understanding of space law are expanded}

The scientific literature determines that space law is a set of national and international normative legal acts that are created to ensure the management, regulation of international, national and regional space activities in outer space or on the surface of the Earth and in its atmosphere [Doyle, 2014].

In the relevant Law of the UK Space Industry Act 2018 is determined that the space industry is the start or the return to earth of a space object or plane that carries the space object or any activity in outer space sub-orbital operation, which means start, providing start-up, operation or return to the earth [Hughes, 2018].

Space activities are an enabling component of human activities that have led to unprecedented cooperation and information networking among States and private companies. All of them achieve common advantages by working together, using resources located in space or partially in outer space. In addition, this leads to an increased understanding of the relationship: ManEarth-Sun-Galaxy-Space, their nature and the importance of their relationship.

In recent years, thanks to the use of outer space, mankind has gained new opportunities: global real-time communication (Internet), television, meteorological information, navigation services and monitoring of natural phenomena on Earth. Taking advantage of these advantages has led to greater integration of the world community, greater interdependence among States and a greater understanding of the nature of our cultural and religious differences. Humanity 
has come a long way towards this understanding, tolerance and peace, especially over the past 50 years. However, from the point of view of space law, we are only at the initial stage. We have a long and progressive way to go [Doyle, 2014].

In our view, and taking into account the fact that private States have begun to participate in the use of outer space, the theoretical factors of understanding space law should be expanded by the criteria of the subjects of the use of outer space.

First, space law is a set of norms of international space law, national space law of space States and private space law [Halunko \& Didenko, 2019] that regulate social relations relating to the development, production of space vehicles, launch into outer space, use of near-earth orbit (the order of registration and installation of the legal trajectory of artificial satellites), liability caused to other persons by space objects, the order of research and use of outer space, in particular space bodies.

Secondly, these norms are established by international space legislation, which has been ratified by the space powers and by national space legislation. If the latter does not come into conflict with international space legislation.

Thirdly, the subjects of space lawis: 1) people - envoys of mankind in outer space astronauts (USA), cosmonauts (Russia), taikonaut (China); b) the UNO in General and the UNO Committee on the peaceful uses of outer space for peaceful purposes, in particular the space of States and their unions, for example, the "Great club of space powers", which is using its own rockets from its territory to launch into orbit satellites of its own production. The members of this Association are the USA, China, Russia, France, Japan, Great Britain, India, Israel, Iran and the European Space Agency; 2) private entities that have received from space permissions for the space activities; 3 ) a person with any legal status if they have suffered from space activities.

As for the messengers of humanity in space, they have a specific legal status on spaceships and on natural space bodies. In outer space, jurisdiction over them is exercised by the state whose nationals are there, with the exception of jurisdiction, with respect to property rights. Spacecraft have the jurisdiction of the country in which the spacecraft is registered, or parts of the spacecraft, as happened at the international space station, where each module is registered for different participants in the international project in accordance with the international Declaration of 1998. Therefore, if an offence is committed on cosmic natural bodies, such acts will be regulated by analogy with the law of the sea. It is clear that the model of the law of the sea for the needs of space law requires special refinement.

Fourthly, the absolute limits of the operation of space law are determined by territory outer space, which starts from the upper atmosphere, 100-110 kilometres above the earth's surface - the Karman line and to infinity. However, sometimes, the norms of space law operate below the Karman line. In certain proportions, together with the rules of national law, they regulate legal issues related to the production, registration, launch and disposal of spacecraft and compensation for damage caused by spacecraft to individuals or legal entities.

In other words, despite the fact that space law is created on the basis of international law and national legal systems, it is gradually becoming more and more allocated to a separate complex mega branch of a special law.

Fifth, unlike the planet Earth, time is not a constant in outer space. The launch of rockets, artificial satellites, is carried out on earth time, the country from which the launch is carried out. The same time is registered on artificial satellites. In the case of sea launches from neutral waters, according to the time zone of the state that owns the sea launch pad. However, the 
farther from the Earth the space object created by mankind is removed, the more time is necessary for receipt and action of norms of the law. In addition to the earth time is necessary to add the time of the passage of legal information to the space object (the time of passing the speed of light) plus the time for its processing and finishing to the crew members.

In the future, regulations relating to certain factors affecting the activities of spacecraft crews and members of colonial settlements outside the earth's atmosphere may be adopted by their authorized representatives. In strict accordance with the substantive and procedural rules, space law is provided for and the procedure and method provided for by space law.

Then the time of their entry on the space object or space body on which the crew is located will be local - the time of the crew's life on the spacecraft or the colonial settlement on the space body. Therefore, legal acts shall enter into force not earlier than the moment of their official bringing to the crew of a spacecraft or the population of a colonial settlement on a space body. If the action applies to any person on Earth or the crews of other space ships that equivalent effect is to be set after entering information in the register on the Ground and official publication with the opportunity to review all interested parties, including stakeholders of the spacecraft and crews of the colonies of settlements. But in any case, registration should be carried out in the registers of those States to which the space object or/and the crew or the UN belongs.

Sixthly, as a General rule, produced by space States, only States and private companies with an exceptionally positive reputation can be the subjects of space activities. The space industry is conservative. To make a rocket out of the cosmic laws is difficult and dangerous for the manufacturer, the violation of these norms is considered a crime. The States of the space club are closely monitoring this. At the same time, from the point of view of space law, States are divided into certain categories: States carrying out launches, States organizing launches, States from whose territory the launch is carried out and States from whose installations the launch of spacecraft is carried out.

A separate subject of space law is the UN Committee on the peaceful uses of outer space, on the basis of which international space treaties are developed and concluded. It is an international platform for resolving gaps in international space law and resolving space conflicts [Committee, 2019].

Seventh, violations of space law are subject to international sanctions and national legal responsibility of States. Each violation of international norms of space law, for example, the seizure of a part or a whole space body, will be subject to UN sanctions, namely the sanctions of the UN Security Council. Under the sanctions were the regimes of Muammar Gaddafi in Libya, Saddam Hussein in Iraq. Now under sanctions are the space programs of the DPRK and Iran. Private companies may be subject to civil, administrative and criminal liability for violations of space law in the countries of registration. Managers of private space companies may also be held liable under domestic law.

\section{The sources of space law are supplemented}

Legal custom as a source of space law. Space law is also a right, it has both General and specific features of law. One common feature of law is that the first source of law is legal custom. Rights custom is a rule of conduct legalized by the state (s), historically formed as a result of the repeated repetition of certain actions by people.

Ancient people carefully peered into the starry sky and saw there about 1000-1500 stars, a significant array of scattered information for that time. For the convenience of accounting, 
they are based on imagination United into imaginary pictures in the sky - the constellations. They used the forms we used to come up with over the last 6,000 years. The main purpose of the constellations is to quickly show the location of the star and tell about its features. Despite the fact that the stars in the constellations have different cosmic nature, from that time to the present day the placement of the cosmic body in the constellations are used in astronomy for ease of orientation in the starry sky of our planet.

Consequently, the use of the location of space bodies with reference to the map of the starry sky created by the ancient constellations in space law is a kind of legal custom.

Instant principle. There are artificial satellites that are put into orbit around the space powers, but fly at an altitude of more than 100 kilometres over the territories of other States. According to the sovereignty of the state and individuals over which at an altitude of more than 100 kilometres flying artificial satellites can not prohibit it. After all, since the launch of the first earth satellite on October 4, 1957, none of the powers or an individual has expressed an official protest about this. In practice, it can be argued that the flight of the first satellite gave rise to an instantaneous custom of space law. Thus, the world community recognized this instant principle passively. Instantly, the usual space norm arose that every state has the right to launch spacecraft into space [Malanczuk, 1997]. Now the considered custom should be supplemented by the fact that every individual who has received permission (license) from the space state has the right to launch spacecraft into space. This is the most significant, but not the only instantaneous custom that has been established in space law.

In other instantaneous norms of space law, without claiming to be the ultimate truth, we include new types of technological activities of individual space States and individuals in outer space, in respect of which other States (persons) have not expressed any negative reaction.

First, it is the right of any space power to land its spacecraft on the surface of space bodies. Since the first landing of the Mars-3 automatic interplanetary station (1971), no state has expressed any protest about this, and similar landings have become relatively regular on other planets of the Solar system and their satellites.

Secondly, it is accepted by the world community of the obligation of obligatory sterilization of means of remote contact research of planets, their satellites and other celestial bodies for the purpose of prevention of accidental entering on them of terrestrial bacteria and other forms of life.

Thirdly, the space and private space companies with a scientific purpose "bomb" the cosmic body. So in April 2019, the Japanese spacecraft Hayabusa-2 detonated an explosive charge on an asteroid, which he explores [Clark, 2019]. Now a day, no space state has protested against this.

There are also examples to the contrary where space-faring States have protested against the actions of other actors in the use of outer space. So the Chinese military used a ground rocket to destroy one of its old satellites, orbiting in space. Thus, successfully passing the test for anti-satellite technology. Such actions of China caused sharp protests from other countries. In particular, the United States believes that the development and testing of such weapons by China does not correspond to the spirit of cooperation that both countries seek in the use of weapons in outer space. Despite the fact that a similar experiment was repeated by other States, for example, India, however, it is clear that the instantaneous principle of space law did not occur [Johnson, 2019].

Consequently, the issue of the right of space States to destroy their satellites remained open and should be resolved on the basis of the relevant international space Treaty. 
A separate line is necessary to consider the so-called pseudo instantaneous norms. When private individuals, having sent out to space agencies of space powers their desire to secure ownership of land on the moon and space stars, have not received an answer from them [Wasser \& Jobes, 2008]. These persons began to believe that they had obtained passive consent to the establishment of property rights in respect of these cosmic bodies. Taking advantage of this case, they carry out the "sale" of the lunar surface areas with the issuance of the corresponding "certificate". For example, such a Scam at the end of the last century was organized by businessman Dennis Hope, through the network of his so-called Lunar Embassy. According to this structure, now in different countries of the world, including in Ukraine, more than 3 million sites of a lunar surface basically in the size one acre $(0,4$ hectares) everyone are already sold. From a legal point of view, such sale of AI does not stand up to any criticism. Consequently, the activities of the "Lunar Embassy and other private companies for the sale of parts of the surface of the moon, other planets of the Solar system and stars contradicts the norms of both international and National space law and is such that does not entail legal consequences, and the relevant" certificates have no legal force [Shemshuchenko, 2011].

International and national laws and regulations are the main sources of space law. Primary among them is the Treaty on principles governing the activities of States in the exploration and use of outer space, including the moon and other celestial bodies (hereinafter referred to as the outer space Treaty (1966)), which has been signed and ratified by all space powers and most other States. It is the basis of international space law and defines the basic legal framework of international space law. The Treaty prohibits the placement of nuclear weapons or any other weapons of mass destruction in the orbit of the Earth, the moon, any other celestial body or station in outer space. The Treaty limits the use of the moon and other celestial bodies only for peaceful purposes and expressly prohibits their use for testing any kind of weapons, military manoeuvres or the establishment of military bases, structures and fortifications. However, the Treaty does not prohibit the deployment of conventional weapons in orbit. The Treaty also States that no state may claim ownership of a space body or part of it, and that the sovereignty of States extends only to space objects directly launched by them [Resolution, 1967].

At first glance, the main drawback of the Treaty as a source of law is the lack of an international law enforcement Agency that would ensure its implementation with the help of international coercion. However, for all the years of its existence, it has never been directly violated. Now it undoubtedly needs changes and additions, primarily due to the fact that private companies come into space, and the analyzed Treaty is directed only to States that have real means for the exploration and use of outer space.

Consequently, the outer space Treaty (1966) remains the legal basis for the space activities of States in the exploration and use of outer space, but it requires changes and additions because it does not directly regulate the activities of private companies in space.

Other space-faring Nations ratified treaties: the Agreement on the rescue of astronauts, the return of astronauts and the return of objects launched into outer space [Resolution, 1968], Convention on international liability for damage caused by space objects Convention on cosmic responsibility [Resolution, 1971]. Consequently, these international treaties are fullfledged sources of space law.

There is also an international space Treaty that has not been ratified by space States, namely, the Agreement on the activities of States on the moon and other celestial bodies was signed by the UN on December 18, 1979. This deal would extend international space law to the moon and all other celestial bodies except Earth, including orbits around those bodies. This 
legal act proclaimed the following principles of space activities: the principle of exclusively peaceful use of the moon and other celestial bodies, the principle of equal rights of all States to the study of celestial bodies, the principle of inadmissibility of any claim by any state to extend its sovereignty to any celestial body [Agreement, 1979]. Consequently, the Agreement on the activities of States on the moon and other celestial bodies (1979) is not a direct source of space law for the major space powers.

The so-called Bogotá Declaration of 1976 is a useless source of space law. According to which some Equatorial States tried to establish their state sovereignty over the relevant segments of the geostationary orbit [Bogotá, 1976]. We must understand that the realities of modern international space law is that international space agreements that will be implemented by the world community can only be adopted by permanent members of the UN Security Council, which includes all the leading space States. Other UN member States are almost directly deprived of such an opportunity. Accordingly, the attempts of some Equatorial countries to establish their sovereignty over a certain part of outer space outside the UN failed.

\section{National space laws of the United States of America}

Let us turn to the national space legislation of some States. In this article, we do not have the opportunity to analyze the national legislation of all space powers, so we will focus only on those who made the most space launches.

The United States confidently holds the championship in scientific research and the use of outer space. And this is not surprising, because the first national space law appeared in the United States in 1958, which is logical, because unlike the main rival in the study of outer space — the USSR, American society lived and lives in democracy and the right state. Accordingly, without legislative regulation, it was simply impossible to develop the space industry in the United States.

According to the Law On the National Aeronautics and space act, by the Senate and the House of representatives was placed before the Executive authorities of the States the following main objectives: to conduct activities in space to peaceful purposes for the benefit of all mankind; to provide for the General welfare of the citizens and the security of the United States; to create a civil Agency that will exercise control over aeronautical and space activities funded by the Government of the United States; to promote commercial use of outer space; to stimulate scientific research (for example, with respect to the expansion of human knowledge of the Earth, its atmosphere and space; improving the efficiency, speed and safety of the spacecraft; the development of space vehicles capable of carrying instruments, equipment, materials, and living organisms through space); to ensure U.S. cooperation with other countries in this sphere; to increase the efficiency of public administration of space industry; to introduce standardization in the space sector; to develop a system of energy saving and nationalaspects ground propulsion systems, and minimize environmental degradation caused by such systems; carry out bioengineering research in space; to carry out the identification, tracking, cataloging and characterization of near-earth asteroids and comets with the goal of providing prevention and mitigation of the potential danger of these objects to mankind [National,1958].

This law is important not only for the development of the space industry in the United States but also for the international community, as its provisions have become the basis for the adoption of similar laws of other space powers, as well as have been used in international space treaties. 
However, over time, public relations in the exploration and use of outer space have become more complex. This was primarily due to the potential entry of private space companies into the market of space services.

In response to these challenges, in December 18, 2010 the US Code was supplemented by first section entitled "National and commercial space programs". This is a very important development for practitioners and scientists specializing in space law and others who have an interest in space law. This section represents a significant improvement in the organizational structure and codification of space legislation. Many technical fixes and improvements have been made in it to make it easier for right realization. In addition, the organizational structure of the law is such that it allows for the further development of space law and the improvement of space legislation. The United States seeks to disseminate these provisions internationally through the "best practices" standards for regulating the activities of private space companies [Sukol, 2011].

Such practical approaches to the legal regulation of the use of outer space enable NASA and American private space companies on Earth and in space to develop and test advanced space technologies.

In particular, in the United States in 2019, it is planned to use: 1) a new tool InSight Mars to study the surface of the planet Mars, which will look for signs of life of microorganisms, collect samples, identify resources that can be used in the future Martian expeditions; 2) James Web space telescope, to study the history of our Universe in the infrared range; 3) the solar probe Parker, which "touches the Sun", traveling closer to its surface than any other spacecraft; 4) launched in April 2018, a satellite with a transit survey of exoplanets (TESS) that will search for planets outside our solar system, controlling 200,000 of the brightest and closest to the Sun stars. Work will continue on the development, construction and promotion of new experimental aircraft - X-planes [NASA, 2018].

So, the United States has the most developed national space legislation, which allowed them to become a leading space state. Therefore, scientists, us officials and NASA officials see the prospect of the development of both national and international space law through the dissemination of best practices, standards, to regulate the activities of private space companies in the United States, as models for other space States at the international level.

The second state for success in space is China. China has made significant achievements in the space sector and has become one of the most active players in the space sector. The main points of this process were the deployment in orbit of the first Chinese space station Tiangong-1 (2011) and the landing of a self-propelled automatic station on the lunar surface (14 December 2013) [Tronchetti, 2019].

In early 2019, China announced its plans to colonize the moon. Technological advances and the discovery of a significant source of water near the lunar poles made this idea even more attractive for commercial structures. For example, the first lunar base will be an unmanned stationary object on the surface of the moon. It will be automated with robotics to provide the necessary infrastructure and support systems before the first taikonaut arrive [Chou, 2019]

Summarizing the above, it should be emphasized that China's technological developments are taking place at a high speed, the same cannot be said about the development and implementation of national legislation regulating space activities, which is still at the stage of development.

Unlike the United States, China lacks a systematic and consistent national space legislation. To date, China has adopted only two low-level regulations on the launch and registration of 
space objects. With the growth of Chinese space programs, the lack of structured national space legislation may lead to China's inability to fully comply with its international obligations [Tronchetti, 2019].

This state of Affairs is also understood by Chinese scientists. For example, the Chinese Professor Li, Juqian, notes that now only two Ministerial resolutions directly related to outer space apply to the special national space legislative PRC: On measures for the administration of registration of objects launched into outer space and Temporary measures for the administration of licensing of the launch of civil objects into outer space. In order to improve National space legislation, the scientist proposes: a) to adhere to international law, especially international space law; b) to use the so-called name of law; c) to Use the legislative experience of other countries; d) to integrate and codify existing space rules and other normative documents [Li, 2012]. Since China has a planned market economy, it still manages to regulate space activities by the subordinate regulations of the government.

So, although China has now become a major player in the exploration and use of outer space, however, Chinese scientists convincingly talk about the need to use comparative borrowing legislative experience of other countries.

Russia retains a certain scientific and production potential in the field of space exploration and use. Regulatory and legal regulation of space activities is a key element in ensuring the stable development of space activities. On October 6, 1993, the law of Russia "On space activities" came into force, which became the Central normative act in the structure of legislative regulation of space activities. The law created a legal basis for the implementation of the Russian space program and contained a number of regulatory norms: the organization of space activities, economic conditions for its implementation, issues of space infrastructure, safety of space activities, international cooperation, responsibility in the field of space activities [Law, 1993].

The Russian regulatory framework for space activities consists of a large number of documents of different levels regulating the activities of state authorities, enterprises of various forms of ownership, as well as citizens of Russia. The total number of documents at various levels dealing with space activities is about 400 . Of this number, only about 30 are legislative acts, and the bulk of decisions on the regulation of space activities falls on the documents of the Executive power [Moiseyev, 2018].

Thus, in Russia, the exploration and use of outer space is carried out on the basis of the national law "On space activities" of 1993, which is the main normative act in the structure of the legislation regulating space activities.

Significant progress in the regulation of the use of outer space was achieved by the United Kingdom, which adopted the space Industry Act 2018. The act regulates commercial space activities, sub-orbital measures and related activities that are carried out from the territory of the United Kingdom [Space, 2018].

It should be understood that the Outer Space Act 1986 (the Outer Space Act 1986) continues to regulate the activities of British space organizations abroad, namely the acquisition and launch of spacecraft and the operation of satellites in orbit. In addition, the law under consideration regulates the issue of measures for the provision of spaceports and range control services. According to the Law, any object from which a spacecraft or an aircraft carrier intends to launch a space object is a cosmodrome and must be licensed. The spacecraft is allowed to land only on a licensed spaceport or on a marine mobile installation. Horizontal spaceports with a runway should be adapted to launch space planes and carrier aircraft [Hughes, 2018]. 
The law also stipulates the rights and obligations of the state regulator of space activities. It is determined that the duty to ensure public safety is a priority. Other factors that the regulator should consider include compliance with international obligations, including UN space treaties and recommendations to reduce the amount of space debris. The prohibition of unlicensed space flights is clearly prescribed. The operation of space launch sites and the provision of range control services without a license are prohibited. It is determined that anyone who acts without a license is the perpetrator of the crime. It is determined that the regulator can only issue a license only if it complies with the international obligations of the UK. The regulator may issue a license only if the risks of participation in space flights have been assessed and if such risks are insignificant. In particular, for assessing impacts on the environment [Hughes, 2018].

The new Law "On space industry" (2018) regulates similar activities of the national space organisations in the UK. Also, for the causing of any harm legal responsibility of the operator to obtain the license for space activity. In this case, the subjects of public administration (Secretary of state, regulator and other competent public entities) shall not be legally liable for damage caused by the operator, except in cases of intentional violation or gross negligence.

The considered normative legal acts provide comprehensive legal regulation of the regime of space and sub-orbital activities, with the help of their norms, the existing space and aviation social relations are regulated. Also, these laws contain a number of delegated powers to the secondary legislation, because it is more flexible and can be quickly adapted to the current situation with the development of the space market. [Hughes, 2018].

\section{Commercial space - regulatory factors}

Now on the world stage approved "private space", which begins with the use of outer space at the expense of private business companies. It started with the support of the US government. Private companies can more effectively manage space business projects, attract large private investments, and significantly reduce the cost of space services. Private space companies receive permits (licenses) from space States to launch missiles, manned flights of artificial earth satellites.

The demand for space satellites exceeds supply. The market for space services is open, subject to space rules. Private space companies can occupy a niche in the production and launch of small and medium-class missiles. In parallel, active work is underway to develop legislation on the commercial use of space.

The commercialization of space is carried out by national companies. They invest primarily in information technology services - the use of information satellites and earth sensing satellites. In today's conditions, these issues are satisfactorily regulated by national legislation. There is no significant international controversy if private space companies provide information services in the country of registration or to other States under contracts. However, attempts by private companies to provide the entire surface of the globe (in fact, consumers of foreign countries) with the high-quality Internet will lead to international legal forms of confrontation on the part of the governments of the States in which the system of the sovereign Internet operates. This issue needs to be addressed by international space law.

The lack of specialized space regulations for private business reduces private investment in space technology and in space in General. For example, if private space companies want to extract natural resources from space bodies (asteroids), they must be sure that such natural 
resources will belong to them on property rights. The extracted natural resources from asteroids will not become the property right of all mankind (UN). Otherwise, they will not invest heavily in such research for decades. An example of a suitable law-making experience to establish the rules of law governing commercial activities in the space sector is the United Kingdom, which adopted the "space industry Act" 2018 [Hughes, 2018; Smith \& Leishman, 2019].

Consequently, the greatest new benefits humanity will receive from outer space. Accordingly, large profits are waiting for private companies that will use outer space for this purpose. For this to happen, effective and transparent national and international law on the use of outer space by private companies is necessary.

\section{Weapons in space: legal aspects}

We have to talk about the military component in space from the very beginning of the creation of space vehicles. It is known that the first ballistic missile released into outer space was the FAA 2 German designer Werner von Braun. It was adopted by the Wehrmacht at the end of world war II. The first satellite of Sergei Korolev was launched on the upgraded Soviet military ballistic missile R 8, and the first cosmonaut Yuri Gagarin flew in his first flight in the capsule of the rocket, where the nuclear warhead was to be located.

In other words, almost before private companies went into space, all launches of space powers were either military or dual in nature. Great tribute should be paid to the governments, at that time the only space powers of the United States and the USSR, which then joined the United Kingdom, were able to develop, negotiate and sign the Treaty on the prohibition of nuclear weapons tests in the atmosphere, outer space and under water of August 5, 1963. Now its participants are 131 States. In the same year, on 13 December, the UN General Assembly adopted the "Declaration of legal principles on the activities of States in the exploration and use of outer space", which, inter alia, determined that States should refrain from the use of outer space for military purposes, respect the right of ownership of registered spacecraft, not to appropriate space objects, comply with international legal sanctions and compensate individuals and legal entities for violations of these principles. It should be noted that space States have so far generally adhered to these rules.

So, if the space powers will strictly adhere to the principles of exploration and use of space, the issues of the militarization of space would not be facing humanity at all. In today's conditions, it should be noted that we should talk about space wars in advance. Fortunately, the space war is still in sci-Fi movies.

The conclusion was reached by Isavella Maria Vasilogeorgi, who believes that the current legal regime of international space law is sufficient to resolve almost all issues that are created by modern technologies. The only problem in this area, the scientist believes, is the need to change the attitude of the governments of space powers to the implementation of space laws and the need for minor adjustments to address a completely new state of Affairs [Vasilogeorgi, 2011].

International space law and public international law may coexist harmoniously with the purpose of maintaining international peace and security in the use of outer space for peaceful purposes. At the same time, the author draws attention to the categorical understanding of the concept of "peaceful purposes", which is defined vaguely in the current space legislation, emphasizing that the use of outer space will be rational if the world community eliminates this discrepancy under the auspices of the UN. This must be done to maintain or even restore international peace and security. Addressing this problem at the national level is a complex 
process that will not produce the desired results. International compromise in this area is necessary to balance the conflicting interests of existing and potential space States that are not yet involved in space activities. Thus, the world community urgently needs international standardization of space terms and expressions in the legal sense. However, the current state of Affairs shows that States lack the political will to do so. Isavella Maria Vasilogeorgi considers that in respect of outer space, member States of the UN must work in close international cooperation. She emphasizes that the sovereignty of the state is not boasting, but an international legal obligation under the UN Charter. States should not engage in aggressive actions in outer space to ensure their national security. States should cooperate on new challenges in outer space on a multilateral basis [Vasilogeorgi, 2011].

However, this does not exclude the use of military satellites, such as spy satellites and military communications. At the same time, formally the above-mentioned agreements are not violated, because such satellites are not technically included in the space-Earth interaction, do not attack people, military equipment and military facilities on Earth.

More dangerous are the experiments of space States to destroy satellites. Now this is done without violating the norms of space law, because the space powers are destroying their artificial satellites, which are registered for them. Back in 1980, the us fighter successfully shot down its satellite in earth orbit, in 2007, China used a missile system to destroy its old satellite in earth orbit, similar actions in 2018 made India.

In the specialized military literature, there is an ongoing discussion of space weapons as elements of missile defence (hereinafter referred to as On) that cannot be used for military strikes on Earth. As well as ground, sea and air-based weapons, which are aimed at military facilities in space. From the point of view of international legal norms, it can be concluded that formally such weapons are not prohibited space weapons, because they are not aimed at defeating anything on Earth. In the context of the loss of the legal effect of the Treaty On the production and deployment of such weapons, it is not a violation of international space law. To bring such weapons to the benefit of mankind? We think not! According to space States, it is necessary to sit down at the negotiating table and voluntarily, compromise and wisely, so that it is safe for all States to limit this arms race.

So, now the placement of any means in outer space that are aimed at the direct impression on the Earth of people, military equipment or objects is a violation of the existing norms of space law. However, the operation of spy and reconnaissance military satellites, the placement in space of missile DEFENSE elements that carry out the interception of military missiles (warheads) of the enemy in outer space, as well as weapons of land, sea and air-based, which can hit military satellites and missiles (warheads) of the enemy in space is not formally a violation of existing space law. In order to stop the arms race in this area, space States must sit down at the negotiating table and voluntarily, compromise and so that it is safe for all to impose certain restrictions and prohibitions. It is not an instantaneous principle that space States attempt to create cannibal satellites that can destroy their own kind in orbit. Most spacefaring Nations have expressed concern on this issue. In accordance with this issue, space States need to sit down at the negotiating table and negotiate, as well.

\section{Space debris: problems of categorical definition and sanctions}

According to some authors, Earth is the overthrow of humanity, it is time to protect it, in our interests and in the interests of future generations, against any harm from human activity. The 
scientist emphasizes that a significant problem is space debris, which from the point of view of space law cannot be considered a space object. However, while remaining in earth orbit, the legal status of space debris from an international comic perspective continues to be established by the basic rules and principles on outer space. According to obligations to protect, inform, consult, provide technical assistance to clean up the earth's near-earth orbit from comic debris should be reflected in the principles of space law [Lafferranderie \& Crowther, 2005].

Another factor in the emergence of space debris is the remains of destroyed satellites. As already noted, on 11 January 2007, China used anti-satellite technology (ASAT) to intercept its own weather satellite at an altitude of about 525 miles above the earth's surface. In this regard, the space powers have criticized the actual interception of the satellite and the minimization of the amount of debris after its actual destruction.

In the foreground is a solution to the problem of space debris wants to be the US. After all, the United States has the most complex and extensive network of space infrastructure and space objects in the world, and therefore intend to more effectively use its advantage in the exploration and use of outer space, through the formation, approval and implementation of international standards for the operation of outer space.

The United States intends to create and prove to the world space community measures of a law-making and law-enforcement nature, namely:

- develop a national standard of the United States, where to determine what is considered "space debris";

- to interpret the norms of international space law: what sanctions will be imposed on violators of the legal regime of observance of pure outer space, that is, on those space companies that leave space debris in the orbit of the Earth.

Such activities of the USA will lead to legal discussion, but this discussion will be a significant factor in solving the problem of space debris. Since it will lead to a discussion of the problem of space debris by a wide range of States and space companies.

Thus, on the destruction of their own satellites and space debris, the space powers are protesting to each other. This state requires an appropriate international legal settlement. The UN office for outer space Affairs should become a platform for such debates.

\section{Advanced task of space law}

More than six decades have passed since the last international fundamental norms of space law were adopted by the international community. It was a time of relative calm. Space law had secondary roles in international and national legal systems and had developed little. Now that the first private companies have successfully launched their missiles into space, the problems of the development of space law are coming to the fore for humanity. After all, outer space (certain places) is a future home for people, it is a large income for private space companies that will provide more and more quality and cheap services for people. Simultaneously, it calls the application to humanity of the ecological damage, and in some cases direct threats to the life and health of people.

The development of space law from the point of view of the militarization of outer space becomes even more urgent. Of course, the near-earth orbit almost immediately became the environment in which military reconnaissance satellites fly. It is clear that ballistic military missiles of space powers reach their goals through outer space. However, the state space was kept, still, place in space weapons active experience. In addition to increased space research, 
the so-called dual-use when space powers to destroy their satellites, practically perfecting the technology of space weapons by destroying enemy satellites.

Consequently, all this poses new challenges to space law, which cannot be described in one article. We will try to determine the directions of development of space law, which in our opinion are:

1. Formation and approval of international standardization of space terms, expressions in the legal sense.

2. To encourage the involvement of private capital in space programmes on the basis of fair competition. This will lead to the development in geometric progression of space exploration, the emergence of new and cheaper existing space and related space services. Outer space is an inexhaustible source of high profits for private companies and social progress for humanity as a whole.

3. Adoption of the foundations, and in the following, the rules of private space law, so that private space companies of different States can interact with each other on the basis of acceptable norms in advance, without applying each time for permits to their governments. This will significantly increase the efficiency of attracting funds from private international companies to the development of outer space, the creation of powerful international transnational private space companies.

4. The resolution of the problems of space debris with the international space law. First of all, it is necessary to register at the international level the concept of "garbage", as well as to determine the types and amount of legal responsibility that will be applied in public or private companies in the case of leaving garbage in the orbit of the Earth.

5. Settlement of ownership of space bodies. Just ignore this problem noting that they are not covered by the classical ownership will not work. Private space companies are already planning to use the natural resources of space bodies. This process can become a conflict, which on the one hand hinders the development of natural resources that are on/in space bodies, on the other hand can lead to space conflicts, including military ones.

6. Development and adoption by the UN security Council of a new international agreement on the use of the resources of the moon and other space bodies for scientific and industrial purposes. Now on the moon actively working probes of China, in the near future will join them at the expense of public programs and private companies of the United States, Russia, Israel. With the creation of transnational space companies, this process will move into an active phase, which sooner or later will lead to conflict situations.

7. Private companies of space States plan to provide services to people from space tourism in large volumes. These issues require special legal regulation to ensure the rights, freedoms and legitimate interests of space tourists. A simple analogy of international law of the sea is no longer sufficient.

8. The world community must work out and approve the agreement of the space powers on legal sanctions that can be applied in private space companies for violation of the norms of space law. An international space court should be established to ensure their fair application and to resolve civil conflicts between private space companies. As for the sanctions that the UN or individual space States may apply to space States or States that seek to become such, they should be spelled out, what actions are subject to sanctions. 


\section{Conclusions}

After a long period of relative stability (stagnation) of space law. humanity has moved to a new stage of its development, which is characterized by the use of outer space at the expense of finances and funds of private companies. Therefore, the world community and space law face new challenges. Objectively, space law is beginning to develop actively. The leading directions of space law development should be: standardization of legal space terms, approval of private space law, promotion of private capital involvement in space programs, development of the theory of the right to use space bodies, regulation of the rights and legitimate interests of space tourists, development of sanctions agreed by the world community for violation of space law, subjects and procedures for their application.

\section{References}

Agreement governing the Activities of States on the Moon and Other Celestial Bodies. New York, 5 December 1979. https://treaties.un.org/Pages/ViewDetails.aspx?src=IND\&mtdsg no $=$ XXIV-2\&chapter $=24 \&$ clang $=$ en

Benkoe, Marietta Edit, Kai-Uwe Schrogl. Space Law: Current Problems and Perspectives for Future Regulation, 2005. https:/www.researchgate.net/profile/Marietta_Benkoe/ publication/224998043_Space_Law_Current_Problems_and_Perspectives_for Future_Regulation/links/5bcf0a 5 fa6fdcc204a015c41/Space-Law-Current-Problemsand-Perspectives-for-Future-Regulation.pdf

Bogotá Declaration. Adopted on December 3,1976. https://bogotadeclaration.wordpress.com/ declaration-of-1976/

Chou, Joshua. How are realistic China's plans to build a research station on the Moon? The Conversation AU. The Conversation, 2019. https://theconversation.com/how-realisticare-chinas-plans-to-build-a-research-station-on-the-moon-109942

Clark, Stephen. Japan's Hayabusa 2 probe releases “bomb” at asteroid. Spaceflight Now, 2019. https://spaceflightnow.com/2019/04/05/hayabusa-2-sci-operation/

Committee on the Peaceful Uses of Outer Space, 2019. http://www.unoosa.org/oosa/en/ ourwork/copuos/index.html

Doyle Stephen E. A Concise History of Space Law: 1910-2009. New Perspectives on Space Law, 2011. http://epizodsspace.airbase.ru/bibl/inostr-yazyki/IISL_Colloquium/2011/ Doyle_A_Concise_History_of_Space_Law_(1910-2009)_in_New_Perspectives_on_ Space_Law_2011.pdf

Greco, Orsola. „Small Satellites”: A Threat for the Future Sustainability of Outer Space Exploration?. Air and Space Law, 2019. Issue 1. pp. 91-110.

Hughes, Louise. The Space Industry Act. U.K. Space Agency, 2018. http://www.unoosa.org/ documents/pdf/copuos/lsc/2018/tech-01.pdf

Halunko, Valentyn, Didenko Sergey. Private International Space Law. Philosophical and Legal Factors of Approval by the World Community. Philosophy and Cosmology. Volume 22, 2019: 16-23. http://ispcjournal.org/journals/2019-22/PhC_22_HalunkoDidenko.pdf

Johnson, Stephen. China Refutes U.S. Claim that it's Pushing Space „Arms Race”. BIG THINK, 2019. https://bigthink.com/politics-current-affairs/china-space

Smith, Lesley Jane, Ruairidh J.M. Leishman. Up, up and Away: An Update on the U.K.'s Latest Plans for Space Activities. Air and Space Law, 2019. 44. pp. 1-26. https://www. 
kluwerlawonline.com/abstract.php?area=Journals\&id=AILA2019001

Lafferranderie, Gabriel, Daphné Crowther. Outlook on Space Law Over the Next 30 Years:

Essays Published for the 30th Anniversary of the Outer Space Treaty. Martinus Nijhoff Publishers, 1997.

Law of Russia On space activities of August 20, 1993 № 5663-I. (Amended on April 15, 2019). http://docs.cntd.ru/document/9033683

LI, Juqian. China's Space Law and Regulation. China University of Political Science and Law, 2012. Nov.9. https://swfound.org/media/95017/li-china_space_law_regulationnov2012.pdf

Malanczuk, Peter. Akehurst's Modern Introduction to International Law. Routledge, 1997. https://books.google.com.ua/books/about/Akehurst_s_Modern_Introduction_to_ Intern.html?id=4doebHRhGT8C\&redir_esc $=y$

Moiseyev, I. Regulatory and legal regulation of space activities in Russia. Institute of space policy, 2018. http://ispolicy.ru/publications/?id=3

National Aeronautics and Space Act of 1958, Pub. L. No. 2. 85-568. The National Aeronautics and Space Administration, 2008. https://history.nasa.gov/spaceact-legishistory.pdf

Resolution adopted by the General Assembly 2345 (XXII). Agreement on the Rescue of Astronauts, the Return of Astronauts and the Return of Objects Launched into Outer Space, 1967. http://www.unoosa.org/oosa/en/ourwork/spacelaw/treaties/ rescueagreement.html

Resolution 2777 (XXVI). Convention on International Liability for Damage Caused by Space Objects. UNOOSA. 1971. http://www.unoosa.org/oosa/en/ourwork/spacelaw/treaties/ introliability-convention.html

Shemshuchenko. Yu. It didn't come to space wars. Veche, 2011. http://veche.kiev.ua/ journal/2498/

Space Industry Act 2018. The National Archives of Legislation the UK government, 2018. https://www.legislation.gov.uk/ukpga/2018/5/contents

Sukol, Rob. Positive Law Codification of Space Programs: The Adoption of Title 51, United States Code. Journal of Space Law, 2011. VOL. 37. pp. 1-38.

Tronchetti, Fabio. Space Law and China. Planetary Science. Oxford Research Encyclopedias, 2019. https://doi.org/10.1093/acrefore/9780190647926.013.66

Vasilogeorgi, Isavella Maria. Military uses of outer Space: Legal Limitations, Contemporary Perspectives. Journal of Space Law. VOL. 39:2, 2011. pp. 379-451

Wasser, Alan, Douglas Jobes. Space Settlements, Property Rights, and International Law: Could a Lunar Settlement Claim the Lunar Real Estate It Needs to Survive, 73 J. Air L. \& Com. 37, 2008. https://scholar.smu.edu/jalc/vol73/iss1/3

What's Next for NASA? NASA, 2018. https://www.nasa.gov/about/whats_next.html 